\title{
Web Tabanlı Yatırımcı Illişkileri Yönetimi Uygulamaları: Borsa İstanbul'da İşlem Gören Sigorta Sektörü Şirketleri Üzerine Bir Analiz
}

\author{
Practices of Web- Based Investor Relations Management: An Analysis of \\ Insurance Sector Companies Which Traded İstanbul Stock Exchange
}

\author{
Doç. Dr. Fatih Temizel - Yrd. Doç. Dr. S. Fatih Kostakoğlu
}

\section{Öz}

Halka arz edilen şirketlerin en büyük hedefi daha yüksek piyasa değerine ulaşabilmektir. Bu gerçek, finansal piyasalardaki aktörler ile ilişkilerin yatırımcı ilişkileri yönetimi uygulamaları ile yönlendirilmesi ihtiyacın ortaya koymaktadir. Dolayısiyla web siteleri önemli bir iletişim aracı olarak karşımıza çıkmaktadır. Çalışmada Borsa İstanbul'da işlem gören Sigorta Sektörü şirketleri analiz edilmiştir. Analizde web tabanl yatırımo ilişkileri yönetiminde kullanılan araçlardan yararlanılmış ve bu araçlar Türkiye Yatırımcı İlişkileri Derneğinin (TÜYID) hazırladığı Skor Kart’a göre analiz edilmiştir. Analize konu olarak Sigorta Sektöründe faaliyet gösteren şirketler seçilmiştir. Bunun nedeni, sektörün yurt içi ve yurt dışı yatırımoı açısından artan önemidir. Elde edilen puanlara göre Sigorta Sektöründe web tabanl yatırımcı ilişkileri uygulamalarında en başarılı şirketin Avivasa Emeklilik ve Hayat A.Ş (AVISA) oldu$\breve{g} u$ ve diğerlerinin onu takip ettiği görülmektedir.

Anahtar Kelimeler: Yatırımcı İlişkileri, Sigortacılık Sektörü, Skor Kart

\footnotetext{
Abstract

The ultimate goal of the companies which are publicly traded is access to higher market values. In this case, the relationship between the actors and the companies in the financial markets need to direct the investor relationship management applications. Thus, websites come across as an important communication tool. In
}

this study, we analyze that insurance companies which are traded Istanbul Stock Exchange. In the analysis, it is utilized a web-based tools for managing investors relations and these tools is analyzed according to score card which is prepared by Turkey Investor Relations Association (TUYID). As the subject of the analysis, it has been selected companies which operates insurance sector. The reason is that increasing importance of sector in terms of domestic and foreign. According to obtained score, the most successful company in the insurance sector with regards to practices in web- based investor relations is Aviva Emeklilik ve Hayat A.S (AVISA) and other companies seem to follow it.

Keywords: Investor Relations, Insurance Sector, Score Card

\section{Giriş}

Halka arz edilen şirketlerin en büyük hedefi daha yüksek piyasa değerine ulaşabilmektir. Bu gerçek, finansal piyasalardaki aktörler ile ilişkilerin yatırımcı ilişkileri yönetimi uygulamaları ile yönlendirilmesi ihtiyacını ortaya koymaktadır. Şirketlerin finansal piyasalardaki aktörler ile iletişim kurma çabaları, güven inşa etmek ve devamında inşa edilen güveni sürdürülebilir kılmak için vazgeçilmezdir.

Doç. Dr. Fatih Temizel, Anadolu Üniversitesi, ftemizel@anadolu.edu.tr Yrd. Doç. Dr. S. Fatih Kostakoğlu, Anadolu Üniversitesi, sfkostakoglu@anadolu.edu.tr 
Anılan hedef kitleye ulaşma çabasının en önemli aracı olan web siteleri, bu nedenle araştırma konusu edilmiştir. Çalışmada Borsa İstanbul'da işlem gören Sigorta Sektörü şirketlerinin web tabanlı yatırımcı ilişkileri yönetiminde kullandıkları araçlar; faaliyet raporları, web siteleri ve finansal sonuç açıklama tabloları Türkiye Yatırımcı İlişkileri Derneği’nin (TÜYID) hazırladığı Skor Kart’a göre analiz edilmiştir. Çalışmaya konu olarak Sigorta Sektöründe faaliyet gösteren şirketlerin seçilmesinin arka planında Sigorta Sektörü’nün Türkiye açısından artan öneminin yanı sıra sektörün çok sayıda ve çeşitlilikte bölgesel ve küresel paydaş ile iletişimde olması yer almaktadır.

Sigorta Sektörü pek çok ülkede Türkiye'dekinin aksine finansal sistemin başrol oyuncusu olarak konumlanmıştır. Türkiye'de bu rol bankalara verilmiştir. Buna rağmen hızla büyümekte olan ve önemli gelişim potansiyeli sergileyen bir Sigorta Sektörü bulunmaktadır. Sigorta Sektörü şirketleri finansal sistemde hem fon arz eden hem de fon talep eden konumundadir. $\mathrm{Bu}$ nedenle yatırımcı ilişkileri yönetiminin hizmetlerinden hem kullanıcı olarak faydalanmakta hem de bu hizmetlerin benzerlerini kendi hedef kitlesine sunmaktadır. Sigorta Sektörünün hedef kitlesinde ulusal ve uluslararası finansal piyasalar ve bu piyasalarda faaliyet gösteren çok sayıda finansal kurum ve yatırımcı bulunmaktadır. Bu özelliği dikkate alındığında Sigorta Sektörün'deki web tabanlı yatırımcı ilişkileri uygulamalarının incelenmesi Borsa İstanbul'da hisse senetleri işlem gören diğer şirketler içinde değerli örnekler ortaya koyabilecektir.

Çalışmanın gerçekleştirildiği dönemde sektörün Borsa İstanbul'da işlem gören yedi şirketi bulunmaktadır. Analiz ve değerlendirmeler bu şirketler üzerinde gerçekleştirilmiştir. Bu şirketler: Anadolu Hayat Emeklilik(ANHYT), Avivasa Emeklilik ve Hayat (AVISA), Halk Sigorta (HALKS), Güneş Sigorta (GUSGR), Ray Sigorta (RAYSG), Ak Sigorta (AKGRT), Anadolu Sigorta (ANSGR)'dan oluşmaktadir.

\section{Sigorta Sektörünün Ekonomik Önemi}

Sigorta, aynı risk ile karşılaşma olasılığı bulunanların dayanışma organizasyonu olarak başlamıştır. Zaman içinde ticareti uluslararası alana yaygınlaştıran, girişimci sayısını arttıran, kredi olanakları oluşturan, önemli bir vergi kaynağı olan, fon kaynağı olarak fonları yatırıma aktaran bir faaliyet halini almıştır. Sigorta faaliyetleri yaygınlık kazandıkça ekonomik gelişime ve büyümeye olumlu katkıları da belirginlik kazanmıştır. Bu sayede finansal piyasalar içinde kendisine saygın bir yer bulmuştur. Bu durumun farkına varan ülkeler iki yüz yılı aşkın zamandır ekonomik gelişmelerinde Sigorta Sektörü’nden maksimum fayda elde etmeye çalışmaktadır (Balta, 1997, s.51).

Günümüzde Sigorta Sektörü’ne ilişkin bazı veriler ülkelerin gelişmişlik düzeyinin göstergesi olarak kabul görmektedir. Bir ülkedeki Sigorta Sektörü’nün büyüklüğü, sigortalı sayısı, kişi başına düşen sigorta poliçesi ve kişi başına prim tüketimi ilgili ülkenin ne ölçüde gelişmiş olduğunu tanımlamakta kullanılmaktadır. Ayrıca sigorta kültürü de sosyo-kültürel anlamda önemli bir gelişme olarak değerlendirilmektedir (Uralcan, 2004, s.50-51).

Sigorta Sektörü yalnızca riskleri teminat altına almak ve riskler gerçekleştiğinde hasarın bedelini tazmin etmekle kalmamaktadır. Sahip olduğu özellikler nedeniyle ekonomide bir takım işlevleri de yerine getirmektedir. Sigorta Sektörü’nün ekonomide yerine getirdiği çeşitli işlevler arasında bu çalışmanın ilgi alanına girenler Ekonomik İşlevler olarak tanımlanmaktadır.

Sigorta Sektörü’nün Ekonomik İşlevleri; önemli bir tasarruf kaynağ 1 olmak, sermaye piyasasının gelişmesini sağlayıcı etken olmak, sosyo-ekonomik kayıpların önleyicisi olmak, uluslararası ekonomik ilişkileri ve ticareti genişletici etken olmak, vergi kaynağ olmak ve istihdam sağlayıcı olmak başlıklarında ele alınmaktadır.

Önemli Bir Tasarruf Kaynağı Olmak: Yoksulluk ve ekonomik az gelişmişlik ile mücadelenin bir gereği olarak her toplum sermaye birikimine önem vermek zorundadır (Güneş, 1997, s.44). Planlanan ekonomik büyüme hızı için gerekli sermaye birikimi ekonomiyi sarsıntıya uğratmadan ancak tasarruf ve diş kaynakların gerekli miktarda elde edilmesiyle gerçekleşebilir (Uralcan, 2004, s.61). Sigortacilık faaliyetleri geniş halk kitlelerine yayılabilme özelliğine sahip olduğundan gerek ülke fertlerinin büyük bir kesiminin, gerekse ülke dışı fertlerin gelirlerinin bir kısmını toplama olanağına sahiptir. Bu birikimler yatırım alanlarına aktarıldıklarında milli geliri arttırmaktadır (Uralcan, 2004, s.61). Başarılı uluslararası sigorta 
ve reasürans işlemleri, ülkeye döviz kazandırarak dış ödemeler için nakit olanakları oluşturmaktadır. Yatırımlarının büyük bir bölümü ithal mallarına dayalı gelişmekte olan ülkeler için bu döviz kazancının önemi büyüktür (Genç, 2002, s.5).

\section{Sermaye Piyasasının Gelişmesini Sağlayıcı Etken}

Olmak: Riskleri dağıtmak amaciyla sigortacılık hizmetleri yerine getiren Sigorta Sektörü şirketleri, sigortalıların ödedikleri primlerden oluşan fonları riskin neden olacağı hasarlar meydana gelinceye kadar sermaye piyasasına aktardıklarından bir finansal aracı niteliği taşımaktadır. Diğer bir ifade ile sigorta şirketleri, sigorta poliçeleri gibi araçlarla yatırımlara yöneltilebilecek fonların temin edilmesine katkıda bulunmakta ve bu fonlar finansal araçlar vasitasıyla sermaye piyasasının gelişmesinde etkin rol oynamaktadır. Özellikle hayat sigortası şirketleri bireysel tasarrufları toplamada önemli ișlevleri olan ve en eski finansal aracılardan birisidir. Bu kuruluşlar tasarrufçu özellikleri nedeniyle özel ve kamu teșebbüslerine uzun vadeli yatırım sermayesi sağlayan bir kaynak oluşturmaktadır.

Sosyo-Ekonomik Kayıpların Önleyicisi Olmak: Sigorta faaliyetlerinin temelinde bireylerin karşılaşabilecekleri aynı tür risklere karşı birleşmeleri ve tek başına taşıyamayacakları ekonomik kayıpları, çoğunluğa dağıtarak korunmaları vardır. Sigorta Sektörü şirketleri bu dayanışma işlemlerini organize etmektedir (Uralcan, 2004, s.61). Bu riskler gerçekleştiğinde işyerlerinin kapanması, girişimcilerin iflası, aile dağılmaları, yoksulluk gibi ekonomik kayıplar kaçınılmaz olmaktadır. Özellikle endüstriyel riskler gerçekleştiğinde tazmin olanağı olmadığı sürece ekonomik faaliyetler durmaktadır. Bireysel açıdan ise; iflaslar, ölümler, sakatlanmalar, doğal afetler ve hırsızlık gibi risklerin neden olduğu ekonomik kayıplar doğmaktadır. Hasarın çoğunluğa dağıtılması kayıpları önlemektedir.

Uluslararası Ekonomik İlişkileri ve Ticareti Genişletici Etken Olmak: Sigorta Sektörü şirketleri, uluslararası ticarette üretici veya ihracatçıya ait olan taşımacılık risklerini devralarak, malını rahatlıkla dış pazarlara taşıma olanağı sunmaktadır. Bu sayede dış ticareti genişletici etkide bulunmaktadır. Öte yandan ihracat kredi sigortası ile ihracatçının riskleri için sorumluluk yüklenmek suretiyle finansal dengelerini tehlikeye sokmaksızın, yurtdışına kredili ürün ve hizmet pazarlaması sağlanmaktadır. Sigorta Sektörü gerek yatırıma kaynak olan fonları arttırmak, gerek girişimcinin rizikolarını yüklenmek suretiyle hem üretim güçlerini arttırma, hem de ticareti uluslararası alana taşıma işlevlerini gerçekleştirmektedir. Özellikle taşıma sigortaları ve ihracat kredi sigortası başta olmak üzere çeşitli kredi ve sorumluluk sigortaları, uluslararası ilişkileri ve ticareti genişletici işlevler açısından başta gelen sigorta türleridir (Hızlı, 2007, s.26-27).

Vergi Kaynağı Olmak: Sigorta işlemlerinin ekonomik işlevlerinden bir tanesi de, tasarruflara kaynak teşkil eden vergilere de büyük oranda katkıda bulunmasıdır. Sigorta Sektörü şirketleri yılsonu bilançolarına göre kendilerine düşen vergiyi ödemektedir. Bunun dışında ellerindeki tahvil, hisse senedi, gayrimenkul gibi yatırım unsurlarının da gelir vb. vergilerini ödemektedir. Ayrıca her sigorta poliçesi başına prime oranla gider vergisi, Yangın Söndürme Vergisi, Garanti Fonu, ölüme bağlı hayat sigortalarında Veraset ve İntikal Vergisi gibi vergiler tahakkuk ettirilmektedir.

İstihdam Sağlayıcı Olmak: Sigorta Sektörü’nün ekonomik olarak değerli bir işlevi de istihdama katkıda bulunmasıdır. Sigorta Sektörü’nün istihdama olan katkısı iki yönlü olmaktadır. Birincisi, sigorta sektörü şirketlerinin merkez ve bölge müdürlüklerindeki işgücünün istihdama katkısı ikincisi ise, Sigorta Sektörü şirketlerinin acente, prodüktör, broker gibi birimleri ile istihdama katkısıdır. Sigorta Sektörü şirketleri merkez ve bölge müdürlüklerinde yapısal olarak az sayıda fakat nitelikli işgücü istihdam edilmektedir. Öte yandan Sigorta Sektörü şirketlerinin özellikle acentelerinde çalışan personel sayısı, merkez ve bölge müdürlüklerinde çalışan sayısının çok üzerinde bulunmaktadır. Bu boyutu ile dolaylı olarak istihdama önemli katkıda bulunmaktadır.

\section{Sigorta Sektörü ve Yatırımcı İlişkileri Yönetimi}

Sigorta Sektörü yukarıda verilen bilgiler çerçevesinde özgün bir yapı sergilemektedir. Ekonomik işlevleri ile ele alındığında diğer sektörlerden ayrılmaktadır. Sermaye birikimine ve mobilitesine yön verme özelliği bulunmaktadır. Sermaye piyasasının gelişimine katkı sağlamaktadır. Sermaye piyasaları, tasarruf sahiplerinin yatırımları ve ihtiyaçları için fon desteğine gerek- 
sinimi olan kişilerle buluşmasını sağlayan piyasalardır (Kılıç ve Güçlü, 2015, s.168). Sigorta Sektörü ise sermaye piyasalarında hem fon arz eden olarak hem de fon talep eden aktör olarak yer almaktadır. Bu faktörlerin her biri ayrı ayrı ve birlikte olmak üzere yatırımcı ilişkileri yönetimi uygulamaları ile kamunun aydınlatılması gereğini ortaya koymaktadır.

Sigorta Sektörü’nde faaliyet gösteren şirketlerden bir bölümü halka açıktır. Hisse senetleri borsada işlem görmektedir. Bu nedenle fon talep eden konumundadır. Aynı zamanda Sigorta Sektörü şirketleri sermaye piyasalarında fon arz eden önemli aktörlerdendir. $\mathrm{Bu}$ yapı Sigorta Sektörü şirketlerini hem tasarrufçu hem de girişimci kimliği sahibi yaparak yatırımcı ilişkileri yönetimi uygulamaları ile iç içe kılmaktadır. Tam da bu nedenle Borsa İstanbul'da hisse senetleri işlem görmekte olan Sigorta Sektörü şirketlerinin web tabanlı yatırımcı ilişkileri uygulamalarının analizi diğer sektörlerden bir adım öne çıkmaktadır. Bu önemden kaynaklı olarak çalışmada dünyadaki web tabanlı yatırımcı ilişkileri yönetimi uygulamaları gözden geçirilerek Türkiye'de Sigorta Sektörü'ndeki yapı ortaya konmaktadır.

Paydaşlar şirketlerin kurumsal yönetim uygulamalarının düzeylerini bilmek ve kararlarında kullanmak istemektedir (Benligiray ve Kılıç, 2011, s.777). Kurumsal yönetim, şirkete ilişkin hak ve sorumlulukların paydaşlar arasında dağılımını düzenleyen, şirketlerin yönetim ve kontrolüne ilişkin bir sistem olarak özetlenebilir (Kılıç ve Benligiray, 2012, s.61). Bu sistemde yatırımcıların doğru, zamanında ve güncel bilgiye sahip olmasında web tabanlı yatırımcı ilişkileri yönetimi temel noktayı oluşturmaktadır (Bayram vd. 2009). Bilgiyi yatırımcılara hızlı ve doğru olarak ulaştırmada şirket web siteleri uygun bir mecra olarak kullanılmaktadır. Bu konuda farklı ülkelere ait uygulamaların değerlendirmelerinden bir özet izleyen bölümde sunulmaktadır.

Seitel, internetin yatırımcı ilişkileri açısından bir devrim olduğunu ifade etmektedir. Dünyanın neresinde ve hangi zamanda olursa olsun yatırımciların ilgilendikleri şirkete ilişkin bilgi sahibi olmalarının mümkün olduğunu belirtmektedir (Seitel, 2004, s.371).

Jo ve Kim yüksek etkileşim özelliklerinin olmasının, şirket ve yatırımcılar arasındaki ilişkiyi olumlu etkilediğini belirlemiştir (Jo ve Kim, 2003, s.213-217). Bu durum, şirket web sitelerinin işlevsel bir biçimde tasarlanmasının multimedya özellikleri ile donatılmasından daha önemli olduğunu ortaya koymaktadır.

Hong ve Kiousis, küçük ölçekli şirketlerin web sitelerinin sahip olması gereken başlıca özellikleri erişim, açıklık, içerik, yatırımcı desteği ve teknoloji şeklinde ifade etmektedir (Hong ve Kiousis, 2007, s.25). Erişim; şirketlerin web sitelerinde yer alan yatırımcı linklerine kolay ulaşımın yanında posta, telefon, faks gibi iletişim araçları aracilığıyla sağlanan erişimi de içermektedir. Açıklık; şirkete ilişkin finansal verilerden, bilgilendirme ve kar dağıtım politikası gibi şirketin şeffaf yönetimini yansıtan verilere ulaşmayı kapsamaktadır. İçerik; bütün web sitelerinin birincil parçasını oluşturan ve yabancı dil seçeneğinden şirket tarihçesine, yatırımcıları ilgilendiren bilgileri işaret etmektedir. Yatırımcı desteği; yatırımcıların yardıma ihtiyacı olduğunda ya da herhangi bir ani gelişmede ulaşabilecekleri bağlantıları kapsamaktadır. Yatırımcı desteği, yatırımcıların memnuniyeti ve yatırımcı bağlılığı açısından şirketlerin dikkat etmesi gereken, yatırımcı ilişkilerinin yüzünün yatırımcılara daha fazla dönük olmasını gerektiren bir konudur. Teknoloji ise, web sitelerinin yatırımcı ilişkilerinde ne kadar etkin olarak kullanıldığını ortaya koyan önemli uygulamalardan biridir.

Callison, Fortune 500 listesinde yer alan şirketlerin web sitelerinin, şirketlerin medya ile olan ilişkilerini sürdürme ve korumada kolaylaştırıcı bir etkisi olduğunu belirtmektedir. Medya ilişkileri, basın odası, haber odası, medya, basında çıkan haberler gibi çeşitli başlıklar altında şirket web sitelerinde yer alan linkler, genellikle basın bültenlerini içermektedir (Callison, 2003, s.40). Sanal basın odası olarak değerlendirilebilen bu ortamda, genel olarak şirkete ilişkin bilgiler, ürünlere ilişkin bilgiler, basın bültenleri, fotoğraflar ve iletişim bilgileri yer almaktadır. Lamb ve McKee, basın odası linkinin genellikle basın bültenlerini içermesine karşllık, temel düzeyde telefon numaraları ve e-postalar gibi iletişim bilgilerini kapsadığını belirtmektedir. Bununla birlikte daha iyi web sitelerinin mutlaka şu linkleri de içermesi gerektiğini söylemektedir: Şirkete ilişkin temel veriler, kurumsal tarih, yönetici biyografileri, yüksek çözünürlüklü yönetici resimleri, ürün ve faaliyet resimleri, anlaş1labilir grafik ve tablolar, dönemlik ve ylllı raporlar, yönetici konuşmaları, şirketin geçmişinde yer alan kilometre taşları olarak tanımlanabilecek önemli olay- 
lar, gelecek etkinlikleri gösteren bir takvim bu kapsamdadır (Lamb ve Mckee, 2004, s.90). Gerek ulusal gerekse küresel ölçekte şirkete ilişkin bilgilere erişme konusunda web siteleri kadar medya ilișkilerinin düzenlenmesi ve yönetilmesi önem taşımaktadır.

Amerika Birleşik Devletleri Sermaye Piyasası Kurulu (SEC- Securities and Exchange Commission), üç ana başlığın yatırımcılarla şirket arasındaki iletişimde çok önemli olduğunu belirtmektedir (Wilcox vd., 2005, s.309):

- Şirketin hisse değerini etkileyebilecek herhangi bir şeye ilişkin mutlaka tam bilgi verilmesi,

- Zamanında açıklama yapmak amacıyla elektronik basın bültenleri hazırlamak ya da uluslararası haber ajansları aracıllğııla duyurular yapılması,

- İçeriden bilgi sağlayarak işlem yapmanın engellenmesidir. Bu amaçla yatırımcılar ve şirket arasındaki karşılıklı bilgi akışında bu maddelere uygun davranılması bir anlamda yasal bir zorunluluk olarak da ortaya çıkmaktadır.

Kurumsal yatırımcılar iyi organize olmuş ve kontrol edilebilen yatırımcı ilişkileri programına sahip şirketlere yatırım yapma konusunda daha isteklidir (Dolphin, 2004, s.28). Amerika Birleşik Devletleri'nde yaşanan Enron, WorldCom gibi şirket skandallarından sonra şirket ve yatırımcılar arasında karşılıklı güvenin oluşturulması için yatırımcı ilişkileri yönetiminin gerekliliği ve önemi ortaya çıkmıştır (Laskin, 2009, s.209).

Yatırımcı ilişkileri mevcut ve potansiyel yatırımcılar yanında finansal analistlere ve genel olarak finansal topluluğa devaml, planlı, kısa ve uzun vadeli ilişkileri yapılandıracak ve sürdürecek bilgiler sunmalıdır. Daha geniş bir ifadeyle yatırımcı topluluğu ve işletme arasında doğrudan ya da dolaylı olarak ortak bir etkileşim ve bağlantı sağlamalıdır (Dolphin, 2004, s.26). Yatırımcılar şirketlerin değerlendirilmesinde finans dışı boyutları giderek daha fazla dikkate almaya başlamıştır. Dolayısıyla şirketlere ilişkin yalnızca sayılar değil yapılan işin doğası, uzun dönemli stratejisi şirket hakkında finansal olmayan bilgiler de alım-satım kararlarında etkili olmaktadır (Laskin, 2009, s.214). Tüm bu maddelerin ortak bir biçimde işaret ettiği konu ise yatırımcı topluluk ve şirket arasında açı iletişime bağlı, karşılıklı empati ve anlayışı gerektiren güven faktörünün tesis edilmesidir.
Theaker, Horton'dan web üzerinden gerçekleştirilen iletişim faaliyetlerinde gözetilmesi gereken sekiz temel kural belirtmektedir. Bunlar basitlik, zamanlama, açıklık, tanımlama, esneklik, bireysellik, anlam, ölçülebilirliktir (Theaker, 2006, s.361). Bunun yanında, şirketlerin iletişim faaliyetleri içinde diğer mecraları da kullanması beklenmektedir. Web üzerinden şirketlere ilişkin bilgilere ulaşmak isteyen yatırımcıların web sitesini ziyaret etme amacı iyi belirlenmiş olmalı ve yatırımcının aradığı bilgiyi kolayca ve çekici bir biçimde bulması gerekmektedir. Bir yatırımcı ulaşmaya çalıştığı herhangi bir bilgiyi şirket web sitesinden kolaylıkla bulamıyor ya da ulaştığı bilgi kendisini tatmin etmiyorsa bir daha o siteyi ziyaret etmeyebilir. Bu da yatırımcı ilişkilerini web siteleri üzerinden yürütmeye çalışan şirketler için olumsuz bir durum oluşturur.

Hedlin'in Stokholm Borsası'ndaki şirketlerin web sitelerinde yatırımcı ilişkilerini değerlendirdiği araştırması, şirketlerin üç aşamada web sitelerinin etkinliğini ortaya çıkardığını belirlemektedir. Öncelikle web sitelerinin oluşturulup çalışır duruma getirilmesi, sonrasinda interneti kullanarak finansal bilginin yayılımının sağlanması ve son olarak web sitelerinin potansiyelinin değerlendirilerek kendine has özelliklerinin sağladığı avantajların kullanımı ortaya çıkmaktadır. Bu eğilimin web sitelerinde genel olarak ortaya koyduğu özellikler ise finansal raporlar, hiper linkler, grafikler, basın bültenleri, yüklemeler, dinamik güncellemeler ve diğer dillerde sunulan bilgiler olarak belirtilebilir (Hedlin, 1999, s.373-381). Hamid'in Kuala Lumpur Borsası'nda yaptığı benzer çalışmada ise şirket web sitelerinde yatırımcı ilişskileri linklerinin birincil amacının yatırımcıları bilgilendirmek olduğu saptanırken web sitelerinde en fazla yer alan bilginin ise şirketin tarihçesi olduğu belirlenmiştir. Hamid, bunun yanında gelişmiş ve gelişmekte olan ülkelerin şirket web sitelerinde yatırımcı ilişkileri yönetimi açısından büyük ve önemli farklılıklar bulunduğunu belirtmektedir (Hamid, s.2005, s.5-14).

Şirketlerin web sitelerinde yayınladıkları finansal bilgileri, içinde bireysel yatırımcıların da bulunduğu geniş bir kullanıcı grubunun erişebileceği biçimde tasarlamaları önemlidir. Web siteleri, yatırımcı ilişkileri yönetiminde yönetici sunumlarından yönetim kurulu toplantı çağrılarına kadar geniş bir içeriği sunmaya uygundur. Web sitelerinin bir başka avantajı ise içinde grafik, metin, video ya da ses dosyalarını içeren çoklu format ve dildeki dokümanları talep eden yatırım- 
cılara sunabilme potansiyelini taşımasıdır (Ettredge ve Gerdes, 2005, s.95). Web sitelerinin sağladığ 1 bu avantajlar kullanılırken aşırı bilgiye boğulmuş ya da iyi yönlendirme yapamayan bir tasarımdan kaçınılması etkin kullanım için önemlidir. İçerik her zaman önemli bir faktör iken içeriğin tasarım, okunabilirlik, kullanılabilirlik gibi özellikleri gölgede bırakmaması gerekir.

Şirket web sitelerinin görsel tasarımının iyi düzenlenmiş olması, yönlendirme sisteminin iyi çalışması, geribildirim mekanizmalarının çabuk çalışması, kolay kullanım özellikleri taşıması az, öz ve alakalı bilgi taşıması temel özellikler olarak sayılabilir. Ekrandan okumak kağıttan okumaktan daha zor olduğu için metinler çok uzun tutulmamalı; ayrıntılı bilgiye ihtiyaç duyulması halinde bu bilginin e-posta aracılı̆̆ıyla sağlanabilmesi; dünyanın dört bir yanından farklı dillerde bireylerin web sitesini ziyaret etme olasıllğının düşünülmesi etkin bir web sitesi için önemlidir (Theaker, 2006, s.371-373).

\section{Borsa İstanbul'da İşlem Gören Sigorta Şirketlerinin Yatırımcı İlişkileri Web Sayfalarının Analizi}

Türkiye Yatırımcı İlişkileri Derneği (TÜYİD), misyonunu, Türkiye piyasalarının ve şirketlerinin yatırımcılara en iyi şekilde tanıtılmasına ve şirketlerin adil piyasa değerlerine ulaşmalarına katkıda bulunmak ve Türkiye sermaye piyasalarının derinlik kazanmasını desteklemek şeklinde açıklamaktadır. Web siteleri özelinde yatırımcı ilişkileri yönetimi uygulamalarının araştırma ve ölçümlerinin sağlıklı bir şekilde yapılabilmesi adına bir Skor Kart çalışması gerçekleştirmiştir. Şirketlere sorulacak 170 (bankalar için 186) soruyu barındıran Skor Kart; faaliyet raporu (66), finansal sonuç açıklama (45) ve web sitesi (59) soru içeren toplam üç bölümden oluşmaktadır. Çalışmada bu skor kart aracıllığ ile veri toplanmıştır.

Faaliyet Raporu kategorisinde yatırımcı ilişkileri yönetiminde bilgilendirme konusunda hayati önem arz eden yıllık faaliyet raporlarının içeriğinde olması gereken bilgiler ve bu bilgilerin yeterliliği test edilmektedir. Şirketin stratejik hedefleri, sermaye, kar payı dağıtım politikası, sosyal sorumluluk anlayışı, kurumsal yönetime uyum beyanları gibi konulara değinen faaliyet raporu soruları, şirketlerin yatırımc1larla ne denli sağlıklı ve sürekli bir iletişim kurduğunu açılar nitelikte sorulardır. Araştırmada incelenen şirketlerin web sitesinde yayınladığı son yıla ait faaliyet raporu Türkçe ve İngilizce dillerinde incelenmiş ve verilerin güncel olması önemsenmiştir.

Finansal Sonuç Açıklama kategorisinde internet siteleri, basın bültenleri, yatırımcı sunumları ve faaliyet raporları incelenmiştir. Yatırımcıların yatırım girişimleri esnasında oldukça önem verdikleri şirketin mali durumu, gelişimi ve öngörüleri konusunda şeffaf bir yaklaşımla kendileriyle iletişim kurmalarını beklediği şirketler için bu kategorideki sorular ve cevapları yatırımcı ilişkileri yönetimini ne kadar doğru yaptıklarını gösterir niteliktedir. Geçmiş yıllardaki mali yapılar, çeyreksel finansal analizler, kar marjları, satış, fiyatlandırma ve hisse senetleri gibi başlıklara sahip olan Finansal Sonuç Açıklama kategorisinde incelemeler şirketin web sitesinde yayınlanan son raporlardan alınan bilgiler doğrultusunda gerçekleştirilmiş ve güncel bilgiler sağlanmaya çalışılmıştır.

Web Sitesi kategorisinde şirketler ve yatırımcılar arasında direkt bir iletişim sağlanabilmesi için önemi büyük olan internet sayfalarının içerik analizinde sorulan 59 soru genel hatlarıyla, 'yatırımcılar şirket için önemli mali bilgilere ulaşabiliyor mu?', 'yatırımcılar şirketin genel kurul bilgilerine ulaşabiliyor mu?', 'yatırımcılar için özel sunumlar hazırlanmış mı?', 'web sitesi teknoloji ve yeni iletişim araçlarını doğru bir şekilde kullanabiliyor mu?', 'Yatırımcının ulaşması gereken bilgi ve belgeler diğer sitelere (KAP vb.) yönlendirme yapmanın yanı sira web sitelerinde de mevcut mu?' şeklinde sorulan sorulardır.

İncelemede cevaplar "VAR", "YOK" veya "UYGULANAMAZ" şeklindedir. Puanlama, "VAR" cevabı verilen sorulara 1 puan, "YOK" cevabı verilen sorulara 0 puan şeklinde gerçekleştirilmiştir. Her bir şirketin puanları yukarıda belirtilen üç kategori altında ayrı ayrı toplanarak oluşturulmuştur.

Borsa İstanbul'da İşlem Gören Sigorta Şirketlerinin Web Tabanlı Yatırımcı İlişkileri Uygulamaların Karşılaştırılması 


\section{Bulgular}

Faaliyet Raporu Sonuç Tablo 1.

\begin{tabular}{|l|c|c|}
\hline Şirketler & $\begin{array}{c}\text { Faaliyet Raporu } \\
\text { Skor Kart } \\
\text { Toplam }\end{array}$ & $\begin{array}{c}\text { Faaliyet Raporu } \\
\text { Skor Kart } \\
\text { Siralama }\end{array}$ \\
\hline Anadolu Hayat Emeklilik (ANHYT) & 62 & 1 \\
\hline Avivasa Emeklilik ve Hayat (AVISA) & 62 & 2 \\
\hline Halk Sigorta(HALKS) & 61 & 3 \\
\hline Güneş Sigorta (GUSGR) & 60 & 4 \\
\hline Ray Sigorta(RAYSG) & 60 & 5 \\
\hline Ak Sigorta (AKGRT) & 59 & 7 \\
\hline Anadolu Sigorta (ANSGR) & 59 & 6 \\
\hline
\end{tabular}

Skor Kart incelemesinde Borsa İstanbul'da işlem gören Sigorta Sektöründeki 7 şirkete Faaliyet Raporu Kategorisinde 66 soruluk inceleme yapılmıştır. Skor Kart incelemesi sonucunda, Skor Kart çalışmasının Faaliyet Raporu Kategorisinde bu 7 şirketin sıralamasi tablo 1'deki gibi olmuştur.

\section{Faaliyet Raporu Kategorisindeki soru başlıkları:}

- Kurumsal Yönetim İlkeleri; 42 soru

- Faaliyet İçerikleri ve Görsellik; 24 soru

Anadolu Hayat Emeklilik(ANHYT): Kurumsal Yönetim İlkeleri 41/42, Faaliyet İçerikleri ve Görsellik $21 / 24$

Avivasa Emeklilik ve Hayat (AVISA): Kurumsal Yönetim İlkeleri 42/42, Faaliyet İçerikleri ve Görsellik $20 / 24$
Halk Sigorta (HALKS): Kurumsal Yönetim İlkeleri 41/42, Faaliyet İçerikleri ve Görsellik 20/24

Güneş Sigorta (GUSGR): Kurumsal Yönetim İlkeleri 41/42, Faaliyet İçerikleri ve Görsellik 19/24

Ray Sigorta (RAYSG): Kurumsal Yönetim İlkeleri 40/42, Faaliyet İçerikleri ve Görsellik 20/24

Ak Sigorta (AKGRT): Kurumsal Yönetim İlkeleri 40/42, Faaliyet İçerikleri ve Görsellik 19/24

Anadolu Sigorta (ANSGR): Kurumsal Yönetim İlkeleri 40/42, Faaliyet İçerikleri ve Görsellik 19/24

Skor Kart incelemesinde Borsa İstanbul'da işlem gören Sigorta Sektöründeki 7 şirkete Finansal Sonuç Açıklama Kategorisinde 45 soruluk inceleme yapılmıştır.

Finansal Sonuç Açıklama Sonuç Tablo 2.

\begin{tabular}{|l|c|c|}
\hline Şirketler & $\begin{array}{c}\text { Finansal Sonuç } \\
\text { Açıklama } \\
\text { Skor Kart Toplam }\end{array}$ & $\begin{array}{c}\text { Finansal Sonuç } \\
\text { Açıklama } \\
\text { Skor Kart Siralaması }\end{array}$ \\
\hline Anadolu Sigorta (ANSGR) & 35 & 1 \\
\hline Avivasa Emeklilik ve Hayat (AVISA) & 35 & 2 \\
\hline Ray Sigorta (RAYSG) & 34 & 4 \\
\hline Ak Sigorta (AKGRT) & 33 & 5 \\
\hline Halk Sigorta (HALKS) & 33 & 6 \\
\hline Güneş Sigorta (GUSGR) & 32 & 7 \\
\hline Anadolu Hayat Emeklilik (ANHYT) & 31 & \\
\hline
\end{tabular}


Skor Kart incelemesi sonucunda, Skor Kart çalışmasının Finansal Sonuç Açıklama Kategorisinde bu 7 şirketin sıralaması tablo 2'deki gibi olmuştur.

\section{Finansal Sonuç Açıklama Kategorisindeki soru başlıkları}

-Şirket Hakkında Diğer Önemli Gelişme ve Bilgiler; 19 soru

-Mali Tablolar; 14 soru

-Hesap Dönemi Hakkında Önemli Bilgiler; 12 soru

Anadolu Sigorta (ANSGR): Şirkete Hakkında Diğer Önemli Gelişme ve Bilgiler 9/19, Mali Tablolar 14/14, Hesap Dönemine Ait Önemli Bilgiler 10/12

Avivasa Emeklilik ve Hayat (AVISA): Şirkete Hakkında Diğer Önemli Gelişme ve Bilgiler 11/19, Mali Tablolar 14/14, Hesap Dönemine Ait Önemli Bilgiler $10 / 12$
Ray Sigorta (RAYSG): Şirkete Hakkında Diğer Önemli Gelişme ve Bilgiler 11/19, Mali Tablolar 14/14, Hesap Dönemine Ait Önemli Bilgiler 9/12.

Ak Sigorta (AKGRT): Şirkete Hakkında Diğer Önemli Gelişme ve Bilgiler 9/19, Mali Tablolar 14/14, Hesap Dönemine Ait Önemli Bilgiler 10/12

Halk Sigorta (HALKS): Şirkete Hakkında Diğer Önemli Gelişme ve Bilgiler 8/19, Mali Tablolar 14/14, Hesap Dönemine Ait Önemli Bilgiler 9/12

Güneş Sigorta (GUSGR): Şirkete Hakkında Diğer Önemli Gelişme ve Bilgiler 10/19, Mali Tablolar 14/14, Hesap Dönemine Ait Önemli Bilgiler 8/12

Anadolu Hayat Emeklilik (ANHYT): Şirkete Hakkında Diğer Önemli Gelişme ve Bilgiler 11/19, Mali Tablolar 13/14, Hesap Dönemine Ait Önemli Bilgiler $7 / 12$

Web Sitesi Sonuç Tablo 3.

\begin{tabular}{|l|c|c|}
\hline Şirketler & $\begin{array}{c}\text { Web Sitesi } \\
\text { Skor Kart } \\
\text { Toplam }\end{array}$ & $\begin{array}{c}\text { Web Sitesi } \\
\text { Skor Kart } \\
\text { Siralama }\end{array}$ \\
\hline Ak Sigorta (AKGRT) & 40 & 1 \\
\hline Anadolu Sigorta (ANSGR) & 39 & 2 \\
\hline Avivasa Emeklilik ve Hayat (AVISA) & 38 & 3 \\
\hline Ray Sigorta (RAYSG) & 36 & 4 \\
\hline Anadolu Hayat Emeklilik (ANHYT) & 35 & 5 \\
\hline Güneş Sigorta (GUSGR) & 31 & 6 \\
\hline Halk Sigorta (HALKS) & 31 & 7 \\
\hline
\end{tabular}

Skor Kart incelemesinde Borsa İstanbul'da işlem gören Sigorta Sektöründeki 7 şirkete Web Sitesi Kategorisinde 59 soruluk inceleme yapılmıştır.

Skor Kart incelemesi sonucunda, Skor Kart çalışmasının Web Sitesi Kategorisinde bu 7 şirketin sıralaması tablo 3'teki gibi olmuştur.

\section{Web Sitesi Kategorisindeki soru başlıkları:}

-İçerik; 30 soru

-Yoğunluk; 23 soru

-Teknoloji; 6 soru
Ak Sigorta (AKGRT): İçerik 26/30, Yoğunluk 11/23, Teknoloji 3/6

Anadolu Sigorta (ANSGR): İçerik 25/30, Yoğunluk 11/23, Teknoloji 3/6

Avivasa Emeklilik ve Hayat (AVISA): İçerik 26/30, Yoğunluk 9/23, Teknoloji 3/6

Ray Sigorta(RAYSG): İçerik 26/30, Yoğunluk 7/23, Teknoloji 3/6

Anadolu Hayat Emeklilik (ANHYT): İçerik 22/30, Yoğunluk 10/23, Teknoloji 3/6 
Güneș Sigorta (GUSGR): İçerik 23/30, Yoğunluk 6/23, Teknoloji $2 / 6$
Halk Sigorta (HALKS): İçerik 24/30, Yoğunluk 6/23, Teknoloji 1/6

\section{Sonuç}

Genel Toplam Skor Kart Sonuç Tablo 4.

\begin{tabular}{|l|c|c|}
\hline Şirketler & $\begin{array}{c}\text { Skor Kart } \\
\text { Genel } \\
\text { Toplam }\end{array}$ & $\begin{array}{c}\text { Skor Kart } \\
\text { Genel } \\
\text { Siralama }\end{array}$ \\
\hline Avivasa Emeklilik ve Hayat (AVISA) & 135 & 1 \\
\hline Anadolu Sigorta (ANSGR) & 133 & 2 \\
\hline Ak Sigorta (AKGRT) & 132 & 3 \\
\hline Ray Sigorta (RAYSG) & 130 & 4 \\
\hline Anadolu Hayat Emeklilik (ANHYT) & 128 & 5 \\
\hline Halk Sigorta (HALKS) & 125 & 6 \\
\hline Güneş Sigorta (GUSGR) & 123 & 7 \\
\hline
\end{tabular}

Skor Kart incelemesinde Borsa İstanbul'da işlem gören Sigorta Sektöründeki 7 şirketin her biri için Faaliyet Raporu, Finansal Sonuç Açıklama ve Web Sitesi Kategorilerinde toplamda 170 soruluk inceleme yapılmıştır. Skor Kart incelemesi sonucunda Skor Kart çalışmasının genel skor toplamlarında bu 7 şirketin sıralaması tablo 4 'teki gibi olmuştur.

Faaliyet raporu, web sitesi ve finansal sonuç açıklama başlıklarında Skor Kart analizi gerçekleştirilen Sigorta Sektörü şirket skorlarının birbirlerine yakın olduğunu görülmektedir. Avivasa Emeklilik ve Hayat (AVISA), faaliyet raporu ve finansal sonuç açıklama başlıklarında 2. ve web sitesi başlığında 3. sırayı alarak genel sıralamada 1. sırada yer almıştır. Anadolu Sigorta (ANSGR), faaliyet raporu başlı̆̆ında 7., finansal sonuç açıklama başlığında 1 . ve web sitesi başlığında 2. sirayı alarak genel sıralamada 2. sirada yer almıştır. Ak Sigorta (AKGRT), faaliyet raporu başl1ğında 6., finansal sonuç açılklama başlı̆̆ında 4. ve web sitesi başlığında 1. sırayı alarak genel sıralamada 3. s1rada yer almıştır. Ray Sigorta (RAYSG), faaliyet raporu başlığında 5., finansal sonuç açıklama başlığında 3. ve web sitesi başlığında 4. sırayı alarak genel sıralamada 4. sırada yer almıştır. Anadolu Hayat Emeklilik (ANHYT), faaliyet raporu başlı̆̆ında 1., finansal sonuç açıklama başlığında 7 . ve web sitesi başlığında 5. sırayı alarak genel sıralamada 5. sırada yer almıştır. Halk Sigorta (HALKS), faaliyet raporu başlı̆̆ında
3., finansal sonuç açılklama başlı̆̆ında 5. ve web sitesi başlığında 7. sırayı alarak genel sıralamada 6. sırada yer almıștır. Güneș Sigorta (GUSGR), faaliyet raporu başlığında 4., finansal sonuç açıklama başlığında 6 . ve web sitesi başlı̆̆ında 6 . sırayı alarak genel sıralamada 7. sırada yer almıştır.

Çalışma sonucunda Sigorta Sektöründeki 7 şirketin kategoriler ve alt başlıklarından aldıkları puanlar aşa$\breve{g}$ ıda detaylı bir şekilde sunulmaktadır.

Avivasa Emeklilik ve Hayat (AVISA): Faaliyet raporu 62 (kurumsal yönetim ilkeleri 42/42, faaliyet içerikleri 20/24), finansal sonuç açılama 35 (şirkete hakkında diğer önemli gelişme ve bilgiler 11/19), mali tablolar 14/14, hesap dönemine ait önemli bilgiler 10/12), web sitesi 38 (içerik 26/30, yoğunluk $9 / 23$, teknoloji 3/6); toplam 135.

Anadolu Sigorta (ANSGR): Faaliyet raporu 59 (kurumsal yönetim ilkeleri 40/42, faaliyet içerikleri 19/24), finansal sonuç açıklama 35 (şirkete hakkında diğer önemli gelişme ve bilgiler 11/19), mali tablolar 14/14, hesap dönemine ait önemli bilgiler 10/12), web sitesi 39 (içerik 25/30, yoğunluk 11/23, teknoloji 3/6); toplam 133.

Ak Sigorta (AKGRT): Faaliyet raporu 59 (kurumsal yönetim ilkeleri 40/42, faaliyet içerikleri 19/24), finansal sonuç açıklama 33 (şirkete hakkında diğer 
önemli gelişme ve bilgiler 9/19), mali tablolar 14/14, hesap dönemine ait önemli bilgiler 10/12), web sitesi 40 (içerik 26/30, yoğunluk 11/23, teknoloji 3/6); toplam 132.

Ray Sigorta (RAYSG): Faaliyet raporu 60 (kurumsal yönetim ilkeleri 40/42, faaliyet içerikleri 20/24), finansal sonuç açıklama 34 (şirkete hakkında diğer önemli gelişme ve bilgiler 11/19), mali tablolar 14/14, hesap dönemine ait önemli bilgiler 9/12), web sitesi 36 (içerik 26/30, yoğunluk 7/23, teknoloji 3/6); toplam 130.

Anadolu Hayat Emeklilik (ANHYT): Faaliyet raporu 62 (kurumsal yönetim ilkeleri 41/42, faaliyet içerikleri 21/24), finansal sonuç açıklama 31 (şirkete hakkında diğer önemli gelişme ve bilgiler 11/19), mali tablolar 13/14, hesap dönemine ait önemli bilgiler 7/12), web sitesi 35 (içerik 22/30, yoğunluk 10/23, teknoloji 3/6); toplam 128.

Halk Sigorta (HALKS): Faaliyet raporu 61 (kurumsal yönetim ilkeleri $41 / 42$, faaliyet içerikleri 20/24), finansal sonuç açıklama 33 (şirkete hakkında diğer önemli gelişme ve bilgiler 8/19), mali tablolar 14/14, hesap dönemine ait önemli bilgiler 9/12), web sitesi 31 (içerik 24/30, yoğunluk 6/23, teknoloji 1/6); toplam 125.

Güneş Sigorta (GUSGR): Faaliyet raporu 60 (kurumsal yönetim ilkeleri $41 / 42$, faaliyet içerikleri 19/24), finansal sonuç açılama 32 (şirkete hakkında diğer önemli gelişme ve bilgiler 10/19), mali tablolar $14 / 14$, hesap dönemine ait önemli bilgiler $8 / 12$ ), web sitesi 31 (içerik 23/30, yoğunluk 6/23, teknoloji 2/6); toplam 123.

Faaliyet raporları, finansal sonuç açıklamaları ve web siteleri incelenen Borsa İstanbul'da Sigorta Sektöründe işlem gören 7 şirket skorlarının birbirlerine yakınlığı ulaşılabilen en önemli veri olarak göze çarpmaktadir.

Skor Kart genel toplam puanında ilk sırada, faaliyet raporu ve finansal sonuç açıklama kategorilerinde 2 . sirayı ve web sitesi kategorisinde 3. sırayı alan Avivasa Emeklilik ve Hayat A.Ş (AVISA) görülmektedir.
Genel toplam puanında ikinci sırada, faaliyet raporu kategorisinde 7. sırayı finansal sonuç açıklama kategorisinde 1. sirayl, web sitesi kategorisinde 2. siray1 alan Anadolu Sigorta (Anadolu Anonim Türk Sigorta Şirketi) (ANSGR) görülmektedir.

Genel toplam puanında üçüncü sırada, faaliyet raporu kategorisinde 6. sırayı finansal sonuç açıklama kategorisinde 4. sırayı, web sitesi kategorisinde 1. sırayı alan Ak Sigorta A.Ş (AKGRT) görülmektedir.

Genel toplam puanında dördüncü sırada, faaliyet raporu kategorisinde 5. sırayı finansal sonuç açıklama kategorisinde 3. sirayı, web sitesi kategorisinde 4. s1rayı alan Ray Sigorta A.Ş. (RAYSG) görülmektedir.

Genel toplam puanında beşinci sırada, faaliyet raporu kategorisinde 1. sırayı finansal sonuç açıklama kategorisinde 7. sırayı, web sitesi kategorisinde 5. sırayı alan Anadolu Hayat Sigorta A.Ş. (ANHYT) görülmektedir.

Genel toplam puanında altıncı sırada, faaliyet raporu kategorisinde 3. sırayı finansal sonuç açılama kategorisinde 5. sirayl, web sitesi kategorisinde 7. sirayı alan Halk Sigorta A.Ş. (HALKS) görülmektedir.

Genel toplam puanında yedinci sırada, faaliyet raporu kategorisinde 4. sırayı finansal sonuç açıklama kategorisinde 6. sıray1, web sitesi kategorisinde 6. sırayı alan Güneş Sigorta A.Ş. (GUSGR) görülmektedir.

Elde edilen puanlara göre Sigorta Sektöründe web tabanlı yatırımcı ilişkileri uygulamalarında en başarılı şirketin Avivasa Emeklilik ve Hayat A.Ş (AVISA) olduğu görülmektedir. Sektörün diğer temsilcilerinin de Avivasa Emeklilik ve Hayat A.Ş (AVISA) yakından izlediği belirlenmiştir. Sıralamada son sırayı ise 2 puanlık bir farkla Güneş Sigorta A.Ş. (GUSGR) almıştır. Sektör temsilcilerinin birbirine yakın uygulamalarının detaylı yorumlanabilmesi için Borsa İstanbul'da kayıtlı diğer sektör temsilcilerinin uygulamalarının da analiz edilmesi önerilebilir. Böylece daha büyük bir veri seti içinde Sigorta Sektörünün konumu değerlendirilebilir. Uygulamanın bu bakış açısı ile Borsa İstanbul'da işlem gören tüm şirketlere yaygınlaştırılması araştırmacıların bundan sonraki hedefi olarak belirlenmiştir. 


\section{Kaynakça}

Balta, S. G. İ. (1997). Türkiye'de Sigorta Sektörünün Gelişimi, Ekonomideki Yeri ve Önemi, Yüksek Lisans Tezi, Hacettepe Üniversitesi Sosyal Bilimler Enstitüsü, Ankara.

Bayram, F., Temizel F. ve Sarıkaya M., (2009). Yatırımcı İlişkileri Yönetimi: Bir Halkla İlişkiler Aracı Olarak Kullanımı ve Değerlendirilmesi, 1. Uluslararası Halkla İlişkiler Sempozyumu, [sunulmuş bildiri] Girne, KKTC.

Benligiray, Y, Kılıç M., (2011). Halka Açık Şirketler İçin Kurumsal Yönetim Derecelendirme Model Önerisi, T.C. Anadolu Üniversitesi İktisadi ve İdari Bilimler Yayınları No.217. Eskişehir.

Callison, C. (2003). Media Relations and the Internet: How Fortune 500 Company Web Sites Assist Journalists in News Gathering, Public Relations Review. 29: 29-41.

Dolphin, Richard R. (2004). The Strategic Role of Investor Relations, Corporate Communicaitons: An International Journal. Vol: 9 No: 1: 25-42.

Ettredge, M. ve John Gerdes, Jr. (2005). Timeliness of Investor Relations Data at Corporate Web Sites, Communications of the ACM. Vol: 48 No:1.

Genç Ö. (2002). Sigortacilık Sektörü ve Türkiye’de Sigorta Sektörünün Fon Yaratma Kapasitesi, Türkiye Kalkınma Bankası A.Ş.

Güneş, S. (1997). Sigorta Sektörü ve Türkiye Ekonomisindeki Yeri, Yüksek Lisans Tezi, Anadolu Üniversitesi Sosyal Bilimler Enstitüsü, Eskişehir.

Hamid, F. Z. A.(2005). Malaysian Companies' Use of the Internet for Investor Relations, Corporate Governance. Vol: 5 No: 1: 5-14.

Hedlin, P. (1999). The Internet as a Vehicle for Investor Relations: The Swedish Case, The European Accounting Review. 8: 2: 373-381.
Hızl, B, P. (2007). Sigorta Sektörünün Gelişimi, Ekonomik Büyüme Üzerindeki Etkisi ve Türkiye Uygulaması, Çukurova Üniversitesi Sosyal Bilimler Enstitüsü, Adana.

Hong, Y. ve Kiousis, S. (2007). Relationship Maintenance with Financial Publics: An Analysis of Investor Relations on Small Companies' Web Sites, International Communication Association. [sunulmuş bildiri] TBA, San Francisco: CA.

Samsup, J. ve Yungwook K. (2003). The Effect of Web Characteristics on Relationship Building, Journal of Public Relations Research. Vol: 15, No: 3: 199223.

Kılıç, M.ve Güçlü, F. (2015). Bist'te Yer Alan Şirketlere Spk Tarafindan Verilen İdari Para Cezaları Üzerine Bir İnceleme, Çanakkale 18 Mart Üniversitesi Gelişim ve Kalkınma Dergisi, Cilt: 10, Sayı:1.

Kılıç M. ve Benligiray Y., (2012). Kurumsal Yönetim Değerlendirme Süreci, Denetişim, 2012/9.

Lamb, L, F. ve McKee, K, B, (2004). Applied Public Relations: Cases in Stakeholder Management, New Jersey: Lawrence Erlbaum.

Laskin, A, V. (2009). A Descriptive Account of the Investor Relations Profession: A National Study, Journal of Business Communication. Vol: 46, No: 2: 208-233.

Seitel, F. P, (2004). The Practice of Public Relations, New Jersey: Prentice Hall.

Theaker, A, (2006). Halkla İlişkilerin El Kitabı, Çeviren: Murat Yaz, İstanbul: MediaCat Yayınları.

Uralcan, G. Ş. , (2004). Temel Sigorta Bilgileri ve Sigorta Sektörünün Yapısal Analizi, İstanbul: Beta Basım Yayım Dağıtım A.Ş.

Wilcox, D. L. Glen T. C., Philip H. A. ve Warren K. A. (2005). Public Relations Strategies and Tactics, Boston: Pearson Inc.

www.tuyid.org. Erişim Tarihi: 15.03.2016 